Azide photochemistry for facile modification of graphitic surfaces: preparation of DNA-coated carbon nanotubes for biosensing

This article has been downloaded from IOPscience. Please scroll down to see the full text article.

2012 Nanotechnology 23425503

(http://iopscience.iop.org/0957-4484/23/42/425503)

View the table of contents for this issue, or go to the journal homepage for more

Download details:

IP Address: 138.25.168.53

The article was downloaded on 19/04/2013 at 00:14

Please note that terms and conditions apply. 


\title{
Azide photochemistry for facile modification of graphitic surfaces: preparation of DNA-coated carbon nanotubes for biosensing
}

\author{
Minoo J Moghaddam ${ }^{1}$, Wenrong Yang ${ }^{1,5}$, Barbara Bojarski ${ }^{1}$, \\ Thomas R Gengenbach ${ }^{2}$, Mei Gao ${ }^{2}$, Hadi Zareie ${ }^{3,6}$ and Maxine J McCall ${ }^{4}$ \\ ${ }^{1}$ CSIRO Materials Science and Engineering, North Ryde, NSW 2113, Australia \\ ${ }^{2}$ CSIRO Materials Science and Engineering, Clayton, VIC 3169, Australia \\ ${ }^{3}$ Institute for Nano-scale Technology, University of Technology, Sydney, NSW 2007, Australia \\ ${ }^{4}$ CSIRO Animal, Food and Health Sciences, North Ryde, NSW 2113, Australia
}

E-mail: minoo.moghaddam@csiro.au

Received 4 July 2012, in final form 14 August 2012

Published 4 October 2012

Online at stacks.iop.org/Nano/23/425503

\begin{abstract}
A facile, two-step method for chemically attaching single-stranded DNA to graphitic surfaces, represented here by carbon nanotubes, is reported. In the first step, an azide-containing compound, $\mathrm{N}-5$-azido-nitrobenzoyloxy succinimide (ANB-NOS), is used to form photo-adducts on the graphitic surfaces in a solid-state photochemical reaction, resulting in active ester groups being oriented for the subsequent reactions. In the second step, pre-synthesized DNA strands bearing a terminal amine group are coupled in an aqueous solution with the active esters on the photo-adducts. The versatility of the method is demonstrated by attaching pre-synthesized DNA to surfaces of carbon nanotubes in two platforms - as vertically-aligned multi-walled carbon nanotubes on a solid support and as tangled single-walled carbon nanotubes in mats. The reaction products at various stages were characterized by $\mathrm{x}$-ray photoelectron spectroscopy. Two different assays were used to check that the DNA strands attached to the carbon nanotubes were able to bind their partner strands with complementary base sequences. The first assay, using partner DNA strands tethered to gold nanoparticles, enabled the sites of DNA attachment to the carbon nanotubes to be identified in TEM images. The second assay, using radioactively labelled partner DNA strands, quantified the density of functional DNA strands attached to the carbon nanotubes. The diversity of potential applications for these DNA-modified carbon-nanotube platforms is exemplified here by the successful use of a DNA-modified single-walled carbon-nanotube mat as an electrode for the specific detection of metal ions.
\end{abstract}

S] Online supplementary data available from stacks.iop.org/Nano/23/425503/mmedia

\footnotetext{
(c) Content from this work may be used under the terms of the Creative Commons Attribution-NonCommercialShareAlike 3.0 licence. Any further distribution of this work must maintain attribution to the author(s) and the title of the work, journal citation and DOI.

5 Present address: School of Life and Environmental Sciences, Deakin University, Geelong, Vic 3217, Australia.

6 Present address: Nanotechnology Graduate Program, Department of Electrical Engineering, Gediz University, Izmir, Turkey.
}

\section{Introduction}

Carbon-based nanomaterials, including carbon nanotubes and graphene, hold promise as novel scaffolds for biomedical applications and particularly for biosensors, due to their high surface area, extraordinary mechanical and thermal strength, and unique electronic and optical properties [1]. 
Several commercial applications envisaged for graphitic materials, including carbon nanotubes (CNTs), require their modification with single strands of DNA (ss-DNA) [2-6]. To be useful for most applications, the attached ss-DNA molecules must be able to physically bind their partner strands with complementary base sequences to form double helices. Such DNA-modified CNTs may be used as DNA sensors if the attached ss-DNA can bind specifically to partner strands pulled from a solution containing a mixture of DNA molecules $[1,2,7,8]$. Alternatively, the attached ss-DNA may be used to assemble the CNTs into nano-electronic devices by binding to partner strands anchored in desired locations, such as on gold electrodes [9, 10].

Various methods have been developed for modifying CNTs with ss-DNA. Standard procedures for functionalizing CNTs usually first involve oxidation in acid to produce carboxyl and/or hydroxyl groups at reactive sites [11]; then the carboxyl groups are activated, and synthetic ss-DNA, bearing a terminal linker with primary amine group, is coupled covalently to the carboxyl groups through an amide bond. This method has been used to attach DNA to the tips, and defects in the sidewalls, of both multi-walled (MWCNTs) and single-walled (SWCNTs) carbon nanotubes [11-13]. However, the hydrophobic character of CNTs is not substantially altered by immobilization of a few DNA molecules to the tips or side-wall defects, and the CNTs tend to bundle in the salty, aqueous solutions required to form DNA double helices. In contrast, CNTs remain usefully dispersed in aqueous solutions when their sidewalls are coated with DNA. Methods have been developed to physically wrap ss-DNA around CNTs [14, 15].

In a previous work we developed a photochemical method to functionalize the sidewalls and tips of MWCNTs with photo-adducts of azido-thymidine, and subsequently synthesized ss-DNA in situ from reactive hydroxyl groups on the photo-adducts using phosphoramidite chemistry, to produce CNTs with high surface coverage of functional ss-DNA [16]. When released from their solid support, the DNA-coated CNTs dispersed readily in water. The photochemical process permits patterning of the CNTs with DNA, and further expands their uses.

Here we diversify our photochemical reaction reported earlier by investigating the use of a different and more versatile azide compound, N-5-azido-nitrobenzoyloxy succinimide (ANB-NOS), to form photo-adducts with active ester groups on the CNTs, as these allow the subsequent attachment of a variety of biomolecules to the CNT sidewalls and tips, including pre-synthesized DNA. We demonstrate the utility of this method by attaching pre-synthesized ss-DNA to CNT surfaces in two platforms, as vertically-aligned MWCNTs on a solid support, and as tangled SWCNTs in mats. We follow progress in the reaction by characterizing the CNTs at various stages using x-ray photoelectron spectroscopy. We show that the attached ss-DNA molecules are able to bind their partner strands using two different assays, and locate the sites of attachment of the ss-DNA on the CNTs. The potential diversity of applications for these DNA-modified CNT platforms is exemplified by the successful use of a
DNA-modified SWCNT mat as an electrode for the specific detection of metal ions.

\section{Materials and methods}

ANB-NOS was purchased from Pierce (Rockford, IL, USA). SWCNTs were obtained from Carbon Nanotechnologies Inc (Houston, TX, USA). All solvents and buffers were purchased from Sigma-Aldrich, unless stated otherwise, and used without further purification.

\subsection{Synthesis and processing of DNA molecules}

The DNA molecules used in this study were synthesized on a 394 DNA/RNA synthesizer (Applied Biosystems, Foster City, CA, USA) using phosphoramidite chemistry and $1 \mu \mathrm{M}$ scale and processed as previously reported [17].

DNA molecules bearing $3^{\prime}$ terminal amine groups were synthesized for coupling with active esters on the CNTs as described below. To check that the terminal amine group, rather than amine groups on DNA bases, reacted with the active esters on CNTs we performed some reactions with the terminal amine group deprotected and the remaining functional groups on the DNA either protected ('partially deprotected' DNA) or fully deprotected. To prepare the partially deprotected DNA, the DNA molecules, synthesized as described previously, were first treated with a 50/50 mixture of piperidine/dimethylformamide for $2 \mathrm{~h}$ at room temperature to remove the fluorenylmethyloxycarbonyl protecting group from the $3^{\prime}$-amino group. Then they were left to sit in $1 \mathrm{ml}$ of ammonia solution for $20 \mathrm{~min}$ at room temperature to release them from controlled pore glass beads, while still retaining all protecting groups except for that on the $3^{\prime}$ terminal amine. This partially deprotected DNA was coupled to the SWCNTs by procedures described below, and then the remaining protective groups were removed by heating the DNA-modified SWCNTs at $55^{\circ} \mathrm{C}$ for $8 \mathrm{~h}$ in $28 \%$ ammonia solution in a sealed glass vial. The ammonia solution was removed, and the DNA-modified SWCNT sample was washed several times with water and stored in water at $4{ }^{\circ} \mathrm{C}$. Reaction of partially deprotected DNA with the functionalized nanotubes ensured that coupling was through the primary amine at the $3^{\prime}$ end, and eliminated any possibility of coupling through the amine groups on the DNA bases (since such coupling would prevent the DNA from binding its complementary strand). Our experiments showed that both the partially and fully deprotected DNA were functional when coupled to the CNTs, and so fully deprotected DNA was used for all subsequent reactions. However, we describe this method involving partially deprotected DNA in case it is useful for other purposes.

Concentrations of DNA molecules were determined by measuring the absorbance at $260 \mathrm{~nm}$ and using molar extinction coefficients $\left(1 \mathrm{~mol}^{-1} \mathrm{~cm}^{-1}\right)$ of 15400 for adenosine, 11700 for guanosine, 7300 for cytidine, and 8800 for thymidine. 
Names and base sequences of DNA molecules used in this study are as follows. The ss-DNA molecules bearing $3^{\prime}$ amine linkers for covalent attachment to CNTs, as described below, are

$$
\begin{aligned}
& \mathrm{NT}^{\prime} \mathrm{NH}_{2} 3^{\prime}: 5^{\prime} \text { TACGCGAATTGCCACT }\left(\mathrm{CH}_{2}\right)_{7}-\mathrm{NH}_{2} 3^{\prime} \\
& \mathrm{NT}^{\prime} \mathrm{T}_{19} \mathrm{NH}_{2} 3^{\prime}: 5^{\prime}{\mathrm{TACGCGAATTGCCACT}(\mathrm{T})_{19}}-\left(\mathrm{CH}_{2}\right)_{7}-\mathrm{NH}_{2} 3^{\prime} .
\end{aligned}
$$

The ss-DNA molecule with base sequence complementary to $\mathrm{NT}^{\prime}{ }^{\prime} \mathrm{NH}_{2} 3^{\prime}$ and $\mathrm{NT}^{\prime}{ }^{\prime} \mathrm{T}_{19} \mathrm{NH}_{2} 3^{\prime}$ is

\section{NT3' AS:5' AGTGGCAATTCGCGTA3'.}

The ss-DNA molecules bearing $5^{\prime}$ phosphate groups containing the beta emitter [32]P, prepared with $\gamma$-ATP-[32]P and polynucleotide kinase, and used for quantitative analysis of reaction products, are

\section{[32]P-NT3'AS:5' [32]P-AGTGGCAATTCGCGTA3' [32]P-NT3': $5^{\prime}$ [32]P-TACGCGAATTGCCACT3'.}

The ss-DNA molecule bearing a $3^{\prime}$ disulfide group for binding to gold nanoparticles is

$$
\begin{gathered}
\text { Gold3A-SH3 } \left.{ }^{\prime}: 5^{\prime} \text { AGTGGCAATTCGCGTA(T }\right)_{19} \\
-\left(\mathrm{CH}_{2}\right)_{3}-\mathrm{S}-\left[\mathrm{S}-\left(\mathrm{CH}_{2}\right)_{3} \mathrm{OH}\right] 3^{\prime} .
\end{gathered}
$$

These sulfur-containing DNA molecules were synthesized, processed, and attached to gold nanoparticles as described previously [16].

\subsection{Photochemical modification of exposed surfaces in CNT} samples and subsequent coupling with pre-synthesized DNA

The aligned MWCNTs used in this study were grown on a quartz substrate by pyrolysis of iron(II) phthalocyanine under $\mathrm{Ar} / \mathrm{H}_{2}$ at $800-1100^{\circ} \mathrm{C}$ [18]. The exposed ends of the nanotubes were sputtered with gold to form a thin gold-foil coating; subsequently, this gold-foil support with nanotubes attached was lifted off the quartz substrate to present nanotubes with clean ends free from amorphous carbon deposits [18].

Oxidized SWCNTs were prepared by refluxing the SWCNTs in $\mathrm{HNO}_{3}$ or in $\mathrm{H}_{2} \mathrm{SO}_{4} / \mathrm{H}_{2} \mathrm{O}_{2}$ (70\%:30\%) following published methods [17]. These treatments produced carboxylic acid and hydroxyl groups on the tips of the SWCNTs and at defects on their sidewalls [19]. To prepare the mats, $10 \mathrm{mg}$ of oxidized SWCNTs in $250 \mathrm{ml}$ water were filtered through an Isopore membrane (Millipore) with a diameter of $25 \mathrm{~mm}$ and a pore size of $\sim 220 \mathrm{~nm}$. The oxidation step not only helped to obtain cleaner nanotubes, but also improved their dispersion and subsequent filtration process.

Ten microlitres of a $100 \mathrm{mM}$ solution of ANB-NOS in anhydrous acetonitrile was pipetted over $20-25 \mathrm{~mm}^{2}$ of vertically-aligned MWCNTs supported on gold foil, or a 20-25 $\mathrm{mm}^{2}$ piece of SWCNT mat, and allowed to dry at room temperature. The CNT samples were then exposed for various times (typically $5 \mathrm{~min}$, unless otherwise stated) to the irradiation from a $300 \mathrm{~W}$ high pressure mercury lamp at a distance of $10 \mathrm{~cm}$ and under a stream of nitrogen. After irradiation, the samples were washed repeatedly with fresh acetonitrile to thoroughly remove the unreacted ANB-NOS.

Aqueous solutions of ss-DNA molecules with $3^{\prime}$ amine linkers $\left(50 \mu \mathrm{l}\right.$ of $104 \mu \mathrm{M} \mathrm{NT} 3^{\prime} \mathrm{NH}_{2} 3^{\prime}$, or $50 \mu \mathrm{l}$ of $53 \mu \mathrm{M}$ $\mathrm{NT}^{\prime}{ }^{\prime}{ }_{19} \mathrm{NH}_{2} 3^{\prime}$ ) were added to ANB-NOS-modified CNT samples, and the $\mathrm{pH}$ of the supernatant was adjusted to 8-9 with $50 \mu \mathrm{l}$ of $\mathrm{NaHCO}_{3} / \mathrm{Na}_{2} \mathrm{CO}_{3}(0.1 \mathrm{mM})$. The mixture was shaken gently at room temperature for $16 \mathrm{~h}$ to allow the DNA to couple to the nanotubes. During this time, the intensity of UV absorbance at $260 \mathrm{~nm}$ in the supernatant decreased, indicating the removal of DNA from solution. The CNT samples were washed with several changes of autoclaved Milli-Q water. At no time in this procedure were the nanotubes allowed to become dry. The DNA-modified CNT samples were stored under water at $4{ }^{\circ} \mathrm{C}$. The SWCNT mats were detached from the Isopore membranes for all subsequent reactions.

\subsection{SEM imaging of DNA-modified CNTs}

MWCNTs modified with DNA (NT3 $\left.{ }^{\prime} \mathrm{T}_{19} \mathrm{NH}_{2} 3^{\prime}\right)$ were sonicated in an ultrasound bath for $10 \mathrm{~min}$ to release them from the gold-foil support and form a suspension in water. Ten microlitres of the dispersed sample was deposited on a silicon (111) substrate for observation with SEM. Images were obtained using a LEO Supra 55VP SEM (Zeiss) equipped with an in-lens secondary electron detector. The images were manipulated using Scanning Probe Image Processor (SPIP) software, while contrast was enhanced using Adobe Photoshop.

\subsection{Analysis of samples by $x$-ray photoemission spectroscopy (XPS)}

The instruments used for XPS analyses were either an AXIS-HSi (KRATOS Analytical, Manchester, UK) or an ESCALAB 220i-XL (Thermo Fisher Scientific, Waltham, MA, USA), both employing monochromated $\mathrm{Al} \mathrm{K} \alpha$ radiation. The angle of photoelectron emission was $0^{\circ}$ with respect to the surface normal (corresponding to a maximum sampling depth of approximately $10 \mathrm{~nm}$ ). However, in the case of particles or rough surfaces (e.g. CNTs) the microscopic emission angle is ill-defined and the sampling depth may vary from 0 to about $10 \mathrm{~nm}$. Under the standard conditions used, the area analysed on the sample surface is an elliptical spot with nominal dimensions of $0.3 \mathrm{~mm} \times 0.7 \mathrm{~mm}$.

Survey spectra were acquired first to determine all elements present on the surfaces of the CNT samples and to determine their atomic concentrations. High-resolution spectra were then recorded for selected elements (e.g. O, C, $\mathrm{N}$ ) in order to obtain more specific data regarding chemical structure. Chemically different species were quantified by fitting model functions to corresponding spectra (curvefits). Assignments of specific curvefit components are usually ambiguous because in complex systems such as those investigated here most photoelectron peaks have contributions from more than one species or compound. 
2.5. Visual assay of MWCNT and SWCNT samples using TEM and gold nanoparticles labelled with ss-DNA

Gold nanoparticles of diameter $16 \mathrm{~nm}$ were made according to the method of Frens [20]. Molecules with $3^{\prime}$ disulfide linkers (Gold3A-SH3') were bound to the gold nanoparticles as described previously [16].

\subsubsection{Assays for vertically-aligned MWCNTs. A sample} of area $\sim 2-3 \mathrm{~mm}^{2}$ was cut from a larger sample of vertically-aligned MWCNTs supported on gold foil that had been functionalized with ANB-NOS and coupled with a 35-nucleotide (nt) DNA molecule $\left(\mathrm{NT}^{\prime} \mathrm{T}_{19} \mathrm{NH}_{2} 3^{\prime}\right)$. A sample of similar size, cut from vertically aligned, unmodified MWCNTs supported on gold foil, was used as a control. The sample and control were pre-soaked over $2 \mathrm{~h}$ with several exchanges of 50\% Express Hyb (Palo Alto, CA, USA) at $37^{\circ} \mathrm{C}$. Then $50 \mu \mathrm{l}$ of a $50 \%$ solution of ExpressHyb containing $\sim 7 \mathrm{nM}$ gold nanoparticles modified with DNA (Gold3A-SH3 $3^{\prime}$ ) was added, and the samples were gently rocked at $37^{\circ} \mathrm{C}$ overnight. Supernatants were removed and the samples were washed three times with $80 \mu \mathrm{l}$ of $0.1 \mathrm{M} \mathrm{NaCl}$, $10 \mathrm{mM}$ sodium phosphate buffer, $\mathrm{pH} 7$, and stored in $50 \mu 1$ of $0.05 \mathrm{M} \mathrm{NaCl}, 10 \mathrm{mM}$ sodium phosphate buffer, $\mathrm{pH} 7$, at $4{ }^{\circ} \mathrm{C}$. To visualize the samples by TEM, MWCNTs were removed from the gold-foil support by scraping or brief sonication. Once dispersed, $1.5 \mu \mathrm{l}$ of solution was placed on a 200-mesh copper grid prepared with carbon film, and left to evaporate. Grids were placed in the TEM (Philips CM100) and digital images were taken with a Gatan Dual Vision camera.

Ultra-thin vertical cross sections of samples of vertically aligned, DNA-modified MWCNTs on gold foil, to which had been added gold nanoparticles bound with complementary DNA, were also prepared and visualized by TEM. A piece of approximately $1 \mathrm{~mm} \times 3 \mathrm{~mm}$ was cut from the sample prepared as described above, but without the scraping or sonication step so that the MWCNTs remained supported by the gold foil. The sample was placed in a glass specimen jar, and was dehydrated through a series of changes of increasing ethanol concentrations $(50 \%, 70 \%, 95 \%, 100 \%$, $100 \%, 100 \%)$ for 15 min each. Then the sample was placed in 100\% ethanol:resin (1:1 ratio) for $4 \mathrm{~h}$, followed by $100 \%$ resin overnight. A rubber mould was filled with fresh resin, and the sample was placed in the mould and left in an oven at $37^{\circ} \mathrm{C}$ for 6 days to cure the resin. The block was trimmed, and ultra-thin sections were cut using a diamond knife. Sections approximately $150 \mathrm{~nm}$ thick were best for viewing by TEM. The resin was made by mixing together $25 \mathrm{ml}$ Epon, $15 \mathrm{ml}$ araldite, $55 \mathrm{ml}$ DDSA (hardener) and $1.7 \mathrm{ml}$ DMP-30 (accelerator).

2.5.2. Assay for SWCNT mats. Samples of area $\left(\sim 2-3 \mathrm{~mm}^{2}\right)$ were cut from a larger sample of a SWCNT mat that had been photochemically functionalized with ANB-NOS and then coupled with ss-DNA (either the 35-nt NT3 ${ }^{\prime} \mathrm{T}_{19} \mathrm{NH}_{2} 3^{\prime}$ or the 16-nt $\mathrm{NT}^{\prime} \mathrm{NH}_{2} 3^{\prime}$ ). A sample of similar size, but cut from an untreated SWCNT mat, was used as a control. The samples were treated as described above for the MWCNTs, with $16 \mathrm{~nm}$ gold nanoparticles modified with Gold3A-SH3 added, and TEM images collected.

\subsection{Quantification assay of SWCNT mats using [32]P-labelled ss-DNA}

Two pieces of approximately equal size $\left(8-10 \mathrm{~mm}^{2}\right)$ were cut from the mat of SWCNTs that had been modified with the 16-nt DNA molecule, $\mathrm{NT}^{\prime} \mathrm{NH}_{2} 3^{\prime}$. The samples were placed in separate Eppendorf tubes and washed once with $50 \mu \mathrm{l}$ of $50 \%$ ExpressHyb, and then twice with $90 \%$ ExpressHyb, each time with gentle rocking for $30 \mathrm{~min}$ at $37^{\circ} \mathrm{C}$. The DNA molecules NT3 ${ }^{\prime}$ and NT3'AS were labelled with [32P]-phosphate on their $5^{\prime}$ ends and mixed thoroughly in ExpressHyb to make $0.1 \mu \mathrm{M}$ [32P]-NT3' and $0.1 \mu \mathrm{M}$ [32P]-NT3 ${ }^{\prime} \mathrm{AS}$ in $90 \%$ ExpressHyb. Sixty microlitres of these solutions was added to the two samples of DNA-modified SWCNT mats, and the samples were rocked gently at $37^{\circ} \mathrm{C}$ for $5 \mathrm{~h}$. Supernatants containing unbound [32P]-NT3 and $[32 \mathrm{P}]-\mathrm{NT}^{\prime} \mathrm{AS}$ were removed, and the samples were washed three times with $0.3 \mathrm{M} \mathrm{NaCl}, 0.03 \mathrm{M}$ sodium citrate, and $0.1 \%$ SDS, after which no radioactivity was detected in the washes. The SWCNT mats were laid flat on a glass plate, covered with clear plastic film, and exposed to a PhosphorImager screen for imaging and quantification using a Typhoon 8600 Variable Mode Imager (Molecular Dynamics), Image Quant software, and Storage Phosphor mode. To account for differential [32]P-labelling of NT3' and $\mathrm{NT}^{\prime} \mathrm{AS}$, the counts for [32P]-NT3' and [32P]-NT3'AS molecules were accurately determined from stock solutions with known concentrations. The total counts from each DNA-modified SWCNT sample were then corrected and converted to nanomoles of ${ }^{32} \mathrm{P}$-labelled DNA per $\mathrm{mm}^{2}$ of SWCNT sample.

\subsection{Electrochemical detection of copper ions using a DNA-modified SWCNT mat as the working electrode}

The DNA-modified SWCNT mat was assessed for its suitability to detect redox-active metals by electrochemical methods. The electrochemical cell consisted of a threeelectrode system, with the DNA-modified SWCNT mat as the working electrode, platinum foil as an auxiliary electrode, and $\mathrm{Ag} / \mathrm{AgCl}$ from BAS as a reference electrode. In these studies, the complementary ss-DNA, NT3'AS, was added to form double-helical DNA on the SWCNT mat. Cyclic voltammetry (CV) and Osteryoung square wave (OSW) voltammetry were performed using a Power Lab potentiostat interfaced with a Dell computer system. $\mathrm{Cu}^{2+}$ was accumulated on the DNA-SWCNT electrode at open circuit by dipping the electrode into $10 \mathrm{ml}$ of a stirred solution of copper nitrate in $0.05 \mathrm{M}$ phosphate buffered solution ( $\mathrm{pH}$ 5.5). After $5 \mathrm{~min}$, the electrode was removed from the cell, washed thoroughly with purified water, transferred to a cell containing phosphate buffer solution (pH 5.5) without copper, and OSW voltammograms were recorded. The $\mathrm{Cu}^{2+}$ remained bound to the DNA-SWCNT mats during the washing procedure, indicating strong binding. The working electrode was stored 

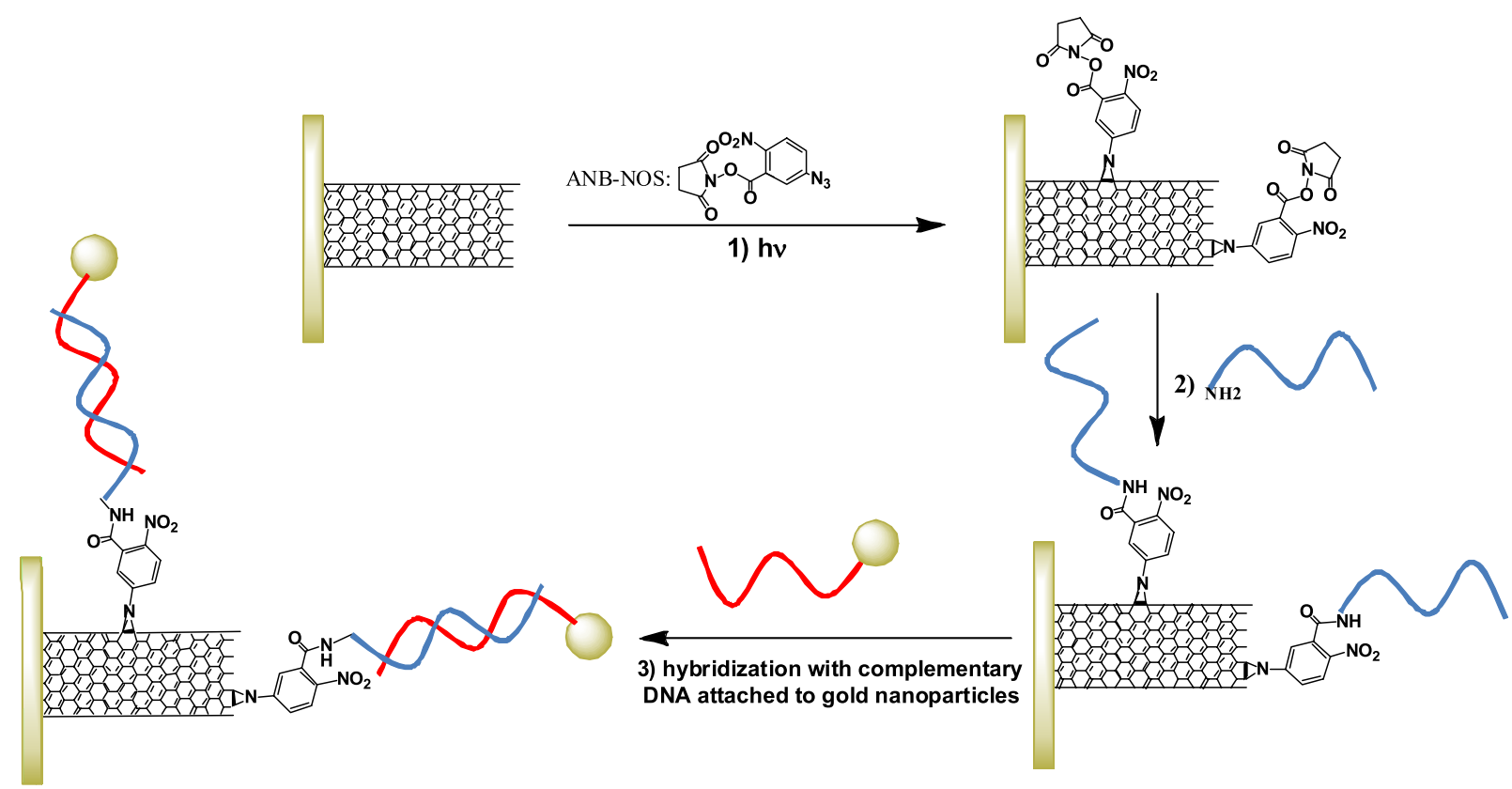

Figure 1. Functionalization of sidewalls and tips of CNTs by photochemical reaction, followed by chemical attachment of ss-DNA and hybridization with DNA strands of a complementary base sequence. (1) Vertically-aligned MWCNTs on a solid support or SWCNT mats are coated with a solution of ANB-NOS, dried and UV irradiated to produce CNTs bearing photo-adducts. (2) The active ester group of ANB-NOS reacts with amino-functionalized DNA (blue strand). (3) The ss-DNAs attached to the CNTs hybridize with DNA strands of the complementary base sequence (red strand) shown here with pre-tethered gold nanoparticles. (Not to scale.)

at $4{ }^{\circ} \mathrm{C}$ until further analysis. The repeatability of the electrode was tested by regenerating to a copper-free electrode by holding the working electrode at $+0.5 \mathrm{~V}$ for $30 \mathrm{~s}$ in $0.1 \mathrm{M}$ $\mathrm{HClO}_{4}$ or dipping the electrode in $1 \mathrm{mM}$ EDTA for $15 \mathrm{~min}$. Repeated cycles did not lead to a significant loss of signal, which indicates that copper remains strongly adsorbed in both oxidation states within the potential range of the experiment. Using either procedure, the electrode could be regenerated without any decrease in response for 5 days, whereupon the current sensitivity began to decrease.

\section{Results and discussion}

\subsection{Photochemical functionalization of CNTs and subsequent chemical attachment of DNA}

The two-step method for covalently attaching ss-DNA to the sidewalls and tips of CNTs is presented schematically in figure 1 . The process is essentially the same for verticallyaligned MWCNTs on a solid support, or the SWCNT mat. In the first step, the CNTs are functionalized with an azido-containing compound in a solid-state photochemical reaction. For this purpose, we used the commercially available, azide-containing compound ANB-NOS. Upon irradiation with UV light, the azide groups of ANB-NOS convert to very reactive nitrene groups that can react with the carbon lattice, producing aziridine groups on their exposed sidewalls and tips; this orients the active ester groups for subsequent reactions. In the second step, ss-DNA molecules are coupled to the nanotubes in aqueous solution via the reaction of the active esters on the photo-adducts and the amine group on the $3^{\prime}$ end of the synthetic DNA. The base sequences of all DNA molecules used in this study are given in section 2.

The ANB-NOS is applied as a solution over the CNT samples in the solid phase. Penetration of the solution into the CNT samples enables a thin film of ANB-NOS to coat the exposed sidewalls of each segregated, vertically-aligned MWCNT standing on a solid support, or exposed surfaces of bundled SWCNTs in the mats. Hence, subsequent coupling with ss-DNA should place DNA on all exposed CNT tips and surfaces.

As a first indicator of the success of the reaction, MWCNTs modified by DNA ( $\left.\mathrm{NT}^{\prime} \mathrm{T}_{19} \mathrm{NH}_{2} 3^{\prime}\right)$ and hybridized with DNA of complementary base sequence (NT3'AS) were imaged by scanning electron microscopy (SEM), in order to see if DNA was present on the surface. White patches were observed all over the walls of the DNA-modified MWCNTs (supporting figure 1S(a) available at stacks.iop.org/Nano/23/ 425503/mmedia), consistent with successful attachment of the ss-DNA. No white patches were seen on the walls of unmodified MWCNTs (figure $\mathrm{S}(\mathrm{b})$ available at stacks.iop.org/ Nano/23/425503/mmedia).

\subsection{Analysis of the reaction products by XPS}

XPS measures the atomic composition of a surface layer of a sample to a maximum depth of $10 \mathrm{~nm}$, detecting and quantifying all elements except for hydrogen and helium. High-resolution spectra of relevant elements can be acquired in order to obtain more specific data regarding chemical bonds and structures. In this study XPS was used to analyse the binding of the photo-adducts to exterior surfaces of the CNT samples, and also to determine the extent of the subsequent 
Table 1. XPS analysis of controls and reaction products to assess the photochemical modification of MWCNTs with ANB-NOS and subsequent coupling with DNA. Data are given as atomic concentrations relative to the total concentration of carbon (i.e. atomic ratios $\mathrm{X} / \mathrm{C}$ ). Control samples: 1, MWCNTs (no treatment); 2, DNA (NT3' $\left.\mathrm{T}_{19} \mathrm{NH}_{2} 3^{\prime}\right)$ added to MWCNTs, soaked for $16 \mathrm{~h}$, then washed off; 3, ANB-NOS added to MWCNTs, then washed off; sample A, ANB-NOS added to MWCNTs, UV irradiated, then washed off; sample B, ANB-NOS added to MWCNTs, UV irradiated, washed off and subsequently reacted with DNA $\left(\mathrm{NT}^{\prime} \mathrm{T}_{19} \mathrm{NH}_{2} 3^{\prime}\right)$. ND; not detected.

\begin{tabular}{|c|c|c|c|c|c|c|}
\hline & \multicolumn{3}{|c|}{ Control samples } & \multicolumn{2}{|c|}{$\begin{array}{l}\text { Photochemically } \\
\text { modified samples }\end{array}$} & \multirow[b]{2}{*}{ Tentative assignments } \\
\hline & 1 & 2 & 3 & A & B & \\
\hline $\mathrm{O} / \mathrm{C}$ & 0.081 & 0.169 & 0.127 & 0.056 & 0.097 & \\
\hline $\mathrm{N} 1 / \mathrm{C}$ & 0.005 & 0.006 & 0.004 & 0.005 & 0.004 & Amines \\
\hline $\mathrm{N} 2 / \mathrm{C}$ & 0.005 & 0.027 & 0.007 & 0.014 & 0.027 & $\begin{array}{l}\text { Amide type }(\mathrm{N}-\mathrm{C}=\mathrm{O} \text {, e.g. amino } \\
\text { acids) }\end{array}$ \\
\hline $\mathrm{N} 3 / \mathrm{C}$ & 0.004 & 0.007 & 0.007 & 0.022 & 0.010 & Protonated/quaternary amines \\
\hline $\mathrm{N} 4 / \mathrm{C}$ & 0.005 & 0.001 & 0.003 & 0.011 & 0.005 & $\mathrm{NO}_{x}$ \\
\hline $\mathrm{N} / \mathrm{C}$ & 0.019 & 0.041 & 0.021 & 0.052 & 0.046 & \\
\hline $\mathrm{P} / \mathrm{C}$ & ND & 0.001 & ND & ND & 0.002 & \\
\hline
\end{tabular}

Table 2. XPS analysis of mats of oxidized SWCNTs photochemically modified with ANB-NOS, with and without subsequent coupling of amine-modified DNA. Data are given as atomic concentrations relative to the total concentration of carbon (i.e. atomic ratios X/C). Control sample: SWCNT mat with no treatment. Sample 1: SWCNT mat treated with ANB-NOS and UV irradiated. Sample 2: SWCNT mat treated with ANB-NOS, UV irradiated, and subsequently reacted with DNA $\left(\mathrm{NT}^{\prime} \mathrm{NH}_{2} 3^{\prime}\right)$. ND; not detected.

\begin{tabular}{llll}
\hline & Control sample & Sample 1 & Sample 2 \\
\hline O/C & 0.027 & 0.091 & 0.098 \\
N/C & ND & 0.007 & 0.026 \\
P/C & ND & ND & 0.003 \\
\hline
\end{tabular}

coupling of ss-DNA by detecting the presence of phosphorus and increased amounts of nitrogen and oxygen. The results of these analyses for the aligned MWCNTs on gold foil are shown in table 1, and for the SWCNT mat in table 2.

Table 1 presents relative concentrations of $\mathrm{N}, \mathrm{O}$ and $\mathrm{P}$ relative to $\mathrm{C}$ in three control samples that were not UV-irradiated (sample 1, pristine MWCNTs; sample 2, MWCNTs exposed to ss-DNA and washed; sample 3, MWCNTs exposed to ANB-NOS and washed) and two UV-irradiated samples (sample A, MWCNTs exposed to ANB-NOS and irradiated; sample B, MWCNTs exposed to ANB-NOS, irradiated, and then reacted with ss-DNA). Note that apart from $\mathrm{C}, \mathrm{O}, \mathrm{N}$, and $\mathrm{P}$ we also detected trace levels of other elements (Fe, F, Si, Au, S, Cl, K, $\mathrm{Na}$; supporting figure $2 \mathrm{~S}$ available at stacks.iop.org/Nano/ 23/425503/mmedia). Both the UV-irradiated sample B with chemically attached DNA and sample 2 with physically adsorbed DNA showed detectable phosphorus compared with other samples, indicating the presence of DNA. Sample B, however, had a higher percentage of nitrogen and phosphorus than Sample 2, suggestive of chemical attachment of the DNA to the nanotubes, although some physical adsorption of DNA in Sample B cannot be excluded.

Survey spectra of all samples and nitrogen highresolution spectra are shown in supporting figures $2 \mathrm{~S}$ and 3S (available at stacks.iop.org/Nano/23/425503/mmedia), respectively. The atomic ratios of oxygen, nitrogen and phosphorous relative to $\mathrm{C}$ (i.e. $\mathrm{X} / \mathrm{C}$ ) for the corresponding photoelectron peaks are listed in table 1. Chemically different species were quantified by fitting model functions to corresponding spectra (curvefits). The corresponding photoelectron peaks due to different chemical bonds for nitrogen are also listed in table 1. It is pertinent to note that assignments of specific curvefit components are usually ambiguous since, in complex systems such as those investigated here, most photoelectron peaks have contributions from more than one species or compound. Despite this limitation, we speculate that the increase in the bond energy at $399.81 \mathrm{eV}$, typical for amides and $\mathrm{N}-\mathrm{C}=\mathrm{O}$ $\left(\mathrm{N} 2 / \mathrm{C}\right.$, table 1), is consistent with the increase of $\mathrm{NO}_{x}$ at $405.01 \mathrm{eV}$ (N4/C, table 1), indicative of chemical attachment of the ANB-NOS in sample A compared to the physically adsorbed sample 3 . The $\mathrm{N} 1 \mathrm{~s}$ at $401.28 \mathrm{eV}(\mathrm{N} 3 / \mathrm{C}$, table 1$)$ may also correspond to the aziridine group which is higher for the photochemically modified sample A than the controls.

Table 2 shows elemental compositions, as determined by XPS, for the non-irradiated, untreated SWCNT mat (control sample), a sample of a SWCNT mat treated with ANB-NOS and irradiated for $9 \mathrm{~min}$ (sample 1), and a sample of a SWCNT mat treated with ANB-NOS, irradiated, and coupled with ss-DNA (sample 2). The control sample, consisting solely of SWCNTs, which had been oxidized in order to clean the surfaces, contains $\mathrm{C}$ and $\mathrm{O}$ but no $\mathrm{N}$ or P. When the SWCNT mat was soaked in ANB-NOS and UV irradiated, and then washed well to remove unreacted ANB-NOS, N was detected and the percentage of $\mathrm{O}$ increased (sample 1) compared to the untreated control. This indicates that ANB-NOS is photochemically attached to the surfaces of the SWCNT mat sample. The presence of $\mathrm{P}$, and the increase in the percentage of $\mathrm{N}$ and $\mathrm{O}$, in sample 2 compared with sample 1 indicates that DNA has been coupled to the ANB-NOS-modified SWCNTs.

Although XPS detected the presence of DNA in the aligned MWCNT sample and the SWCNT mat, thus verifying the successful photochemical reaction and subsequent coupling, the method cannot specify if the attached DNA is functional. We used two assays to determine if ss-DNA attached to CNTs in both platforms is able to bind DNA molecules with a complementary base sequence. 


\subsection{Visual analysis of the reaction products using DNA-modified gold nanoparticles and TEM}

To examine the functionality of DNA molecules tethered to CNTs via their $3^{\prime}$ ends, samples of ss-DNA with a complementary base sequence bound to gold nanoparticles were prepared as described in our previous report [16] and added to samples of the DNA-modified CNTs and control samples with no DNA attached, for comparison. Binding of the partner ss-DNA molecules will place the gold nanoparticles very close to the sites of attachment of functional DNA on the nanotube samples. Subsequent imaging of the gold nanoparticles and CNTs by TEM will reveal the sites of attachment of functional DNA. DNA-modified gold nanoparticles added to unmodified CNT samples, as controls, will reveal the degree of non-specific physical adsorption of ss-DNA (attached to gold nanoparticles) to the bare CNT surfaces under the same experimental conditions. As the diameter of the gold nanoparticles at $16 \mathrm{~nm}$ is larger than the $\sim 2 \mathrm{~nm}$ diameter of double-helical DNA, we tested whether or not steric exclusion of gold nanoparticles from adjacent sites on the CNT surfaces might be an inhibiting factor in the assay, by binding ss-DNA molecules of two different lengths to the CNTs. These ss-DNA molecules contained either $16 \mathrm{nt}$ or $35 \mathrm{nt}$ - the longer molecule had the same sequence of 16 bases as the shorter molecule (for binding to complementary ss-DNA on the gold nanoparticles) plus an additional 19 consecutive thymidines that could serve as a flexible spacer. Our experiments indicated that the $\mathrm{T}_{19}$ spacer had only a minimal effect, but caution that this observation is based on analysis of a limited number of TEM images. We developed this assay previously, and, with various controls, have shown that it is useful for detecting sites of functional DNA molecules attached to CNTs, although care must be taken to avoid false positives caused by DNA strands (tethered to gold nanoparticles) physically adsorbing to bare CNT surfaces [16].

Figure 2 shows TEM images of DNA-modified MWCNTs (a) and unmodified MWCNTs (b) that were treated with DNA-modified gold nanoparticles and then released from the support. The significantly higher numbers of gold nanoparticles decorating the surfaces of the MWCNTs in (a), compared with (b), indicate that the DNA on these gold nanoparticles is hybridized with DNA on the surfaces of the MWCNTs, and therefore the attachment of functional DNA to MWCNTs by the ANB-NOS method was successful. The number and fairly even distribution of the gold nanoparticles all over the surface of the MWCNT in (a) reveals that the coverage of ss-DNA, and hence ANB-NOS, in the photochemical reaction, is uniform.

To determine how representative these images are, we extensively imaged a sample of vertically-aligned, DNAmodified MWCNTs on gold foil to which we had hybridized DNA-modified gold nanoparticles. The CNT sample was embedded in a resin, from which ultra-thin sections were cut using a diamond knife. Figure 3(a) shows overlays of consecutive TEM images taken across a thin section of the
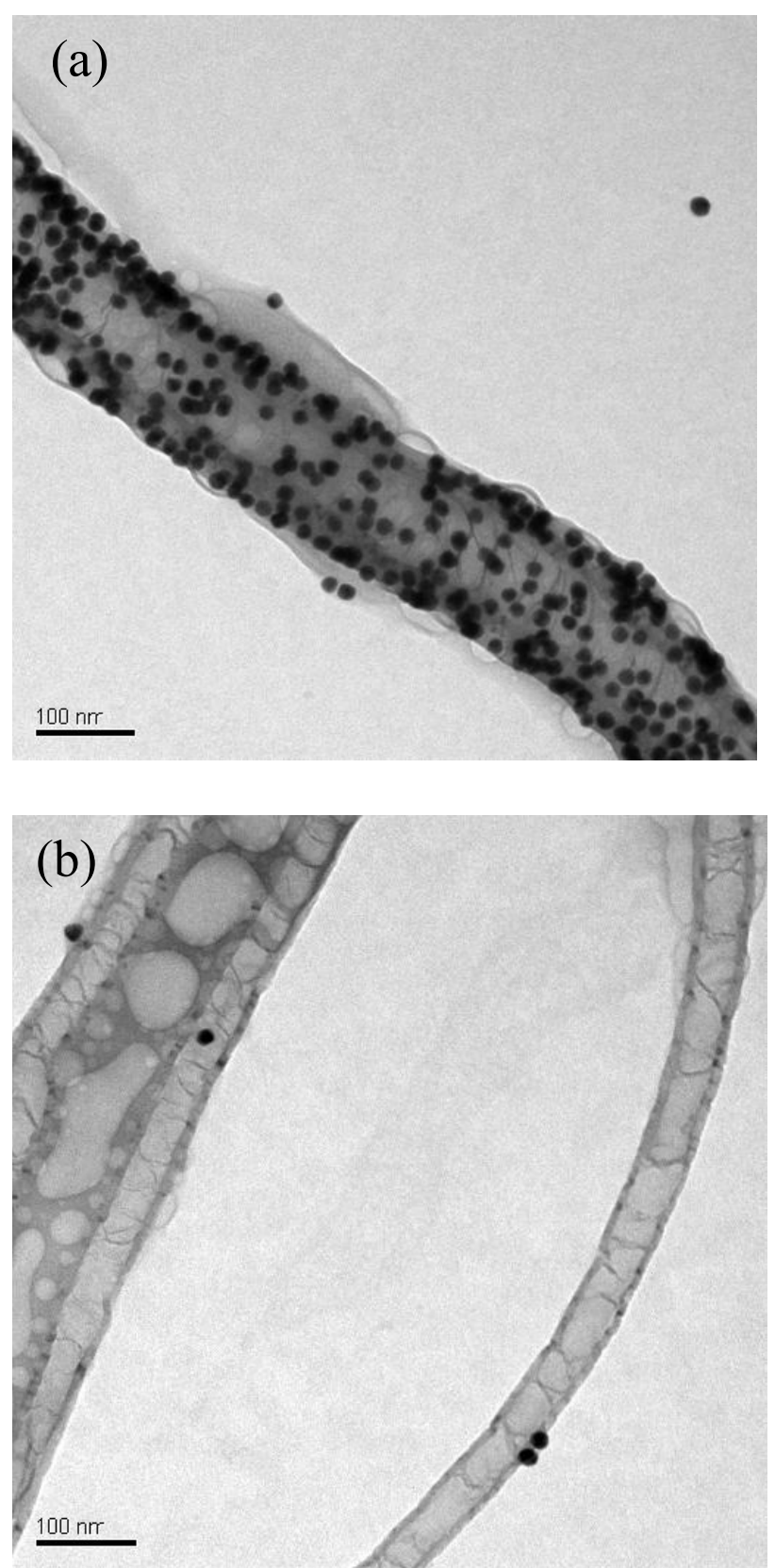

Figure 2. TEM images of gold nanoparticles reveal sites of attachment of functional DNA to MWCNTs. (a) Vertically-aligned MWCNTs, photochemically modified with ANB-NOS and coupled to ss-DNA (NT3' $\mathrm{T}_{19} \mathrm{NH}_{2} 3^{\prime}$ ). (b) Untreated MWCNTs. $16 \mathrm{~nm}$ gold nanoparticles modified with ss-DNA (Gold3A-SH3') were added to both MWCNT samples in the presence of a surfactant. The images reveal that functional DNA is all over the sidewalls of the treated MWCNT samples, with minimal physical adsorption of the DNA-modified gold nanoparticles to the MWCNT control.

sample. Close inspection reveals that gold nanoparticles are close to the surfaces of the MWCNTs across the breadth and depth of the sample. The gold nanoparticles seem to be present in slightly higher concentrations at the tips of the nanotubes than on the sidewalls. Some of the nanotubes appear broken in the image, presumably having been cut by the diamond knife when the sample was prepared. In this sample, most nanotubes have a uniform diameter, although a few are much wider than 


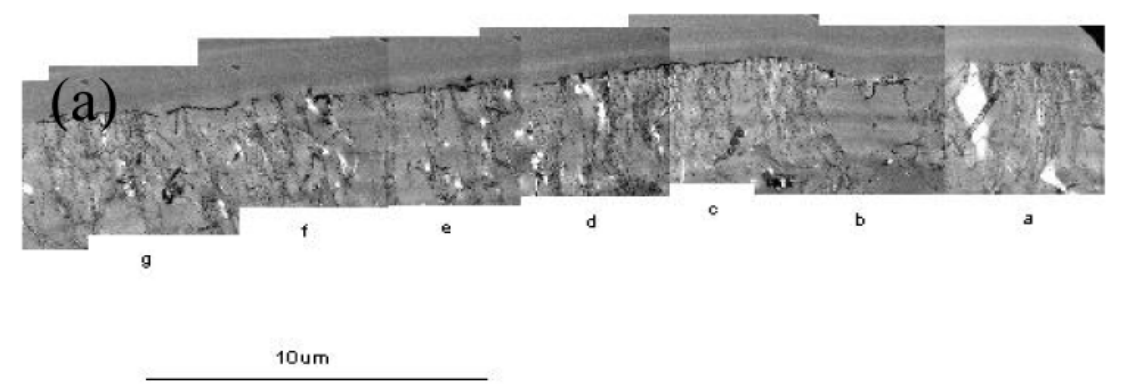

3um

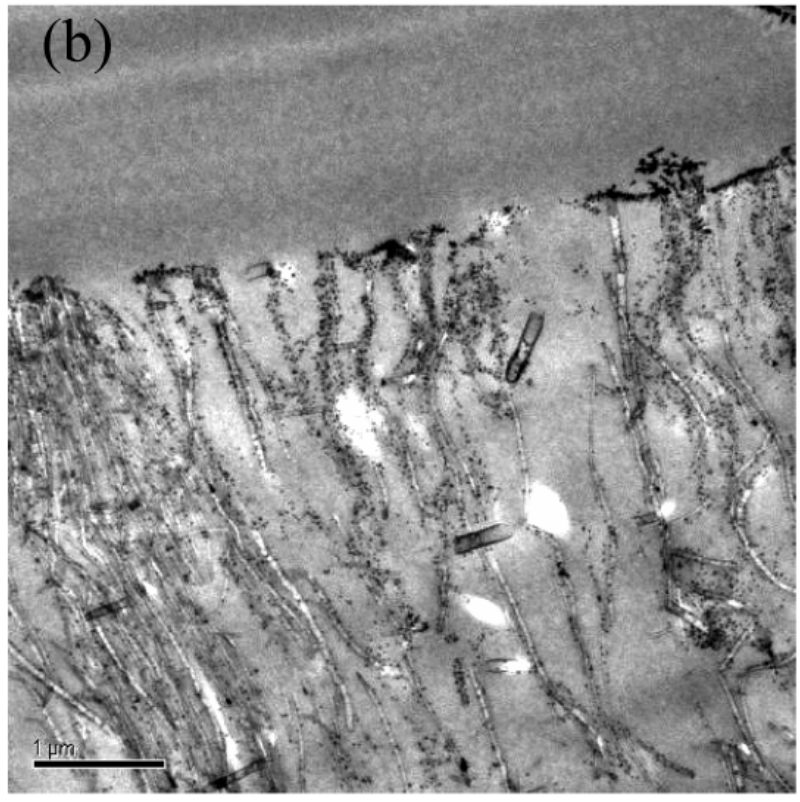

Figure 3. TEM images of DNA-modified gold nanoparticles bound to DNA attached to vertically-aligned MWCNTs. (a) Overlay of consecutive TEM images taken across a thin cross section of the sample. The gold nanoparticles are close to the surfaces of the nanotubes across the length and breadth of the sample, indicating that attachment of DNA to sidewalls and tips of vertically-aligned MWCNTs by the ANB-NOS method was successful. (b) An additional section shown at higher magnification.

the average. Figure 3(b) is an image at higher magnification of an additional section of the sample. These images reveal that functional DNA has been successfully attached to the walls of the MWCNTs extensively throughout the sample.

Figures 4(a)-(c) shows TEM images at low magnification of samples prepared by adding DNA-modified gold nanoparticles to SWCNT mats to which were bound (a) the ss-DNA NT3' $\mathrm{T}_{19} \mathrm{NH}_{2} 3^{\prime}$ with $35 \mathrm{nt}$, (b) ss-DNA NT3 ${ }^{\prime} \mathrm{NH}_{2} 3^{\prime}$ with $16 \mathrm{nt}$, or (c) no DNA, and then gently sonicating pieces cut from the mats to break up the sample for imaging. Large numbers of gold nanoparticles (seen as tiny black dots at this magnification) are dispersed throughout the samples of DNA-modified SWCNTs in (a) and (b). The control, figure 4(c), shows very few gold nanoparticles, indicating there is little non-specific physical adsorption of the DNA-modified gold nanoparticles to the unmodified SWCNTs or bundles of SWCNTs, under the experimental conditions. (The uniformly black area at the top of (c) is due to a mass of SWCNTs; there are no punctuate black spots indicative of gold nanoparticles in this area.) The assay reveals that the binding of the DNA-modified gold nanoparticles to the DNA-modified SWCNT samples in (a) and (b) is through specific DNA hybridization, and hence that functional DNA was successfully attached to the SWCNTs in mats. Figure 4(d) is a higher-magnification image of the sample shown in (b), revealing that the DNA has been attached non-uniformly to the surfaces of the SWCNTs which are present in small bundles. Areas on the SWCNT bundle bearing no gold nanoparticles may have been in direct contact with other bundles when in the mat, and therefore may not have been exposed to ANB-NOS. This higher-resolution image is typical of the SWCNT samples modified with both the 35-nt and the 16-nt DNA molecules, and reveals the extent of coverage of functional DNA on the surfaces of bundles of SWCNTs in mats.

\subsection{Quantitative analysis of the reaction products using [32]P-labelled DNA}

The visual assay using DNA-modified gold nanoparticles enables us to see where functional ss-DNA is attached to 

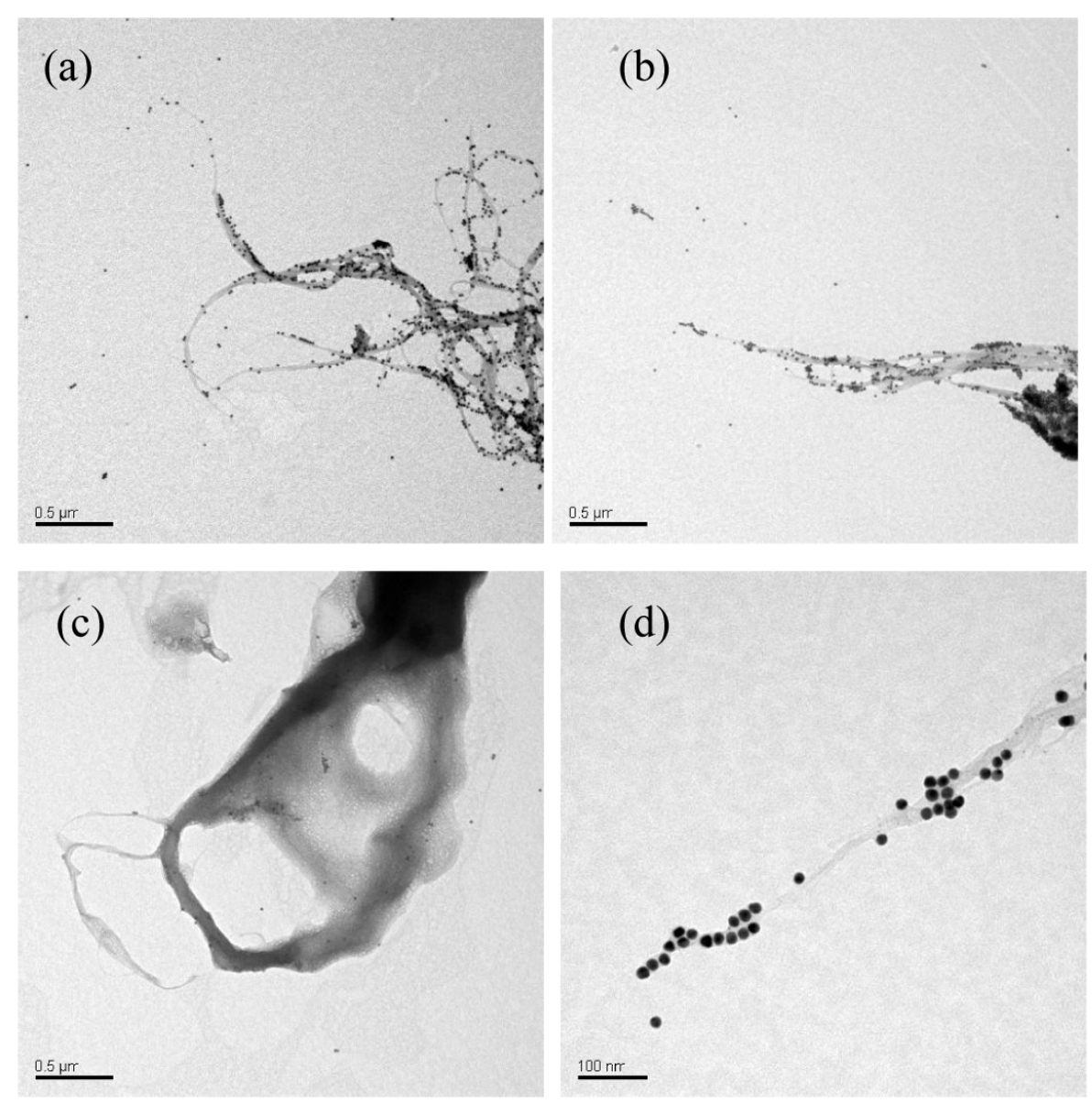

Figure 4. TEM images of bundled SWCNTs dispersed from mats, with gold nanoparticles lining the CNT surfaces. The gold nanoparticles are linked to the SWCNTs by double helices of DNA (not seen at this resolution), revealing the sites of attachment of functional ss-DNA on the CNTs. The SWCNTs were modified with DNA ((a) NT3 ${ }^{\prime} \mathrm{T}_{19} \mathrm{NH}_{2} 3^{\prime}$, and (b) $\mathrm{NT}^{\prime} \mathrm{NH}_{2} 3^{\prime}$ ) or were unmodified (c). Gold nanoparticles of $16 \mathrm{~nm}$ diameter were modified with Gold3A-SH3'. (d) An image at higher magnification of the sample in (b). Scale bars: $500 \mathrm{~nm}$ (a)-(c), $100 \mathrm{~nm}(\mathrm{~d})$.

CNTs. However, it does not necessarily permit a quantitative assessment of the density of functional ss-DNA strands on the CNTs because steric interference or electrostatic repulsion from the DNA-modified gold nanoparticles may prevent some DNA strands on the CNTs from binding to their partner strands. Therefore, we have developed an assay that allows the amount of attached, functional DNA to be quantified. The assay uses ss-DNA strands (with base sequences complementary to those on the CNTs) labelled on their $5^{\prime}$ ends with a phosphate group containing radioactive [32]P. This radioactively labelled DNA is added to the DNA-modified CNTs, and the radioactivity associated with the CNT samples after extensive washing is quantified on a PhosphorImager. We also used [32]P-labelled non-complementary DNA molecules as controls to measure the level of non-specific binding to the DNA-modified SWCNT mats.

Figure 5 shows the level of beta emissions from the [32]P-DNA associated with samples of SWCNT mats modified with $\mathrm{NT}^{\prime} \mathrm{NH}_{2} 3^{\prime}$. The sample on the left shows that very little of the non-complementary [32]P-NT3' is associated with the SWCNT mat, indicating a very low level of non-specific binding to the nanotubes, and/or a small amount of physical entrapment in the mat. In contrast, the sample on the right shows a large amount of the complementary DNA, [32]P-NT3'AS, associated with the sample, indicating that the DNA attached to the SWCNTs is highly functional. The loading of [32]P-labelled DNA molecules in the sample on the right (area $10.2 \mathrm{~mm}^{2}$ ) is $24.8 \mathrm{nmol} \mu \mathrm{m}^{-2}$; this gives an estimate of the packing density of functional DNA molecules attached to the SWCNTs in the mat. The loading of [32]P-labelled DNA molecules in the sample on the left (area $8.2 \mathrm{~mm}^{2}$ ) is $0.2 \mathrm{nmol} \mu \mathrm{m}^{-2}$, indicating that specific binding is over 120-fold higher than non-specific binding to the DNA-modified SWCNT mats. When hybridization and washing conditions are optimized for these novel samples, the signal to noise should increase.

Both the visual assay with DNA-modified gold nanoparticles and the quantitative assay with [32]P-labelled DNA reveal that ss-DNA attached to SWCNT mats is able to specifically bind DNA molecules with complementary base sequences. Hence, this platform shows promise for further development as a DNA biosensor, and other types of sensor. 


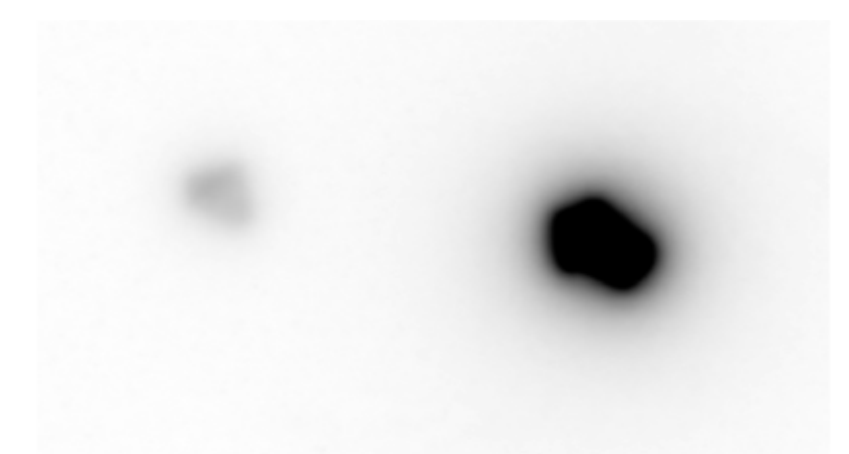

Figure 5. Comparing the extent of non-specific and specific binding of [32]P-labelled DNA to mats of DNA-modified SWCNTs. The SWCNT mats were photochemically modified with ANB-NOS in a solid-state reaction, and then coupled through amide bonds to DNA molecules with amine linkers $\left(\mathrm{NT}^{\prime} \mathrm{NH}_{2} 3^{\prime}\right)$. Low levels of beta radiation from the sample on the left, to which non-complementary [32]P-labelled DNA ([32]P-NT3') was added, indicate a low level of non-specific binding to, and low levels of entrapment in, the DNA-modified SWCNT mat. High levels of beta radiation from the sample on the right, to which complementary [32]P-labelled DNA ([32]P-NT3'AS) was added, indicate that the DNA covalently attached to the SWCNTs in the mat is highly functional and readily able to bind to DNA strands of the complementary base sequence. The areas of the SWCNT mats are $8.2 \mathrm{~mm}^{2}$ (left) and $10.2 \mathrm{~mm}^{2}$ (right).

\subsection{Use of DNA-modified SWCNT mats as working electrodes in sensors}

DNA is rich in nitrogen and oxygen atoms. These atoms enable the DNA to chelate metal ions, either through DNA bases or possibly the phosphate groups, depending on the type of metal ion. This establishes a potential for DNA to be used in sensors for the specific detection of metals. We tested this hypothesis, using DNA-modified SWCNT mats to detect $\mathrm{Cu}^{2+}$ ions. Electrochemical detection of complexed metal ions is achieved by directly measuring the voltammetry of the metal ion when bound to DNA in the modified SWCNT mat used as an electrode. A SEM image of the DNA-modified SWCNT mat used in these experiments is shown in figure 6(a).

Under the $\mathrm{pH}$ conditions employed for the accumulation of copper ions ( $\mathrm{pH} 5.5$ ), both oxygen and nitrogen atoms of DNA bases are likely to be involved in binding the metal $[21,22]$. The cyclic voltammogram of a DNA-modified SWCNT mat electrode after pre-concentration for 5 min in copper ions $(0.01 \mathrm{mM})$ is shown in figure $6(\mathrm{~b})$. The oxidation and reduction behaviour is indicative of $\mathrm{Cu}(\mathrm{II})$ to $\mathrm{Cu}(\mathrm{I})$ electrochemistry which implies that $\mathrm{Cu}(\mathrm{I})$ is also stabilized by complexation with the DNA bases. $\mathrm{Cu}$ (II) to $\mathrm{Cu}(\mathrm{I})$ electrochemistry has been reported previously for $\mathrm{Cu}$ (II) bound to peptide-modified electrodes [23]. This is confirmed as a surface redox process by the equality, and linear dependence on sweep rate, of the oxidation and reduction peak currents, in contrast to the dependence of peak current on the square root of sweep rate that is characteristic of a redox process in which diffusion of a reactant from solution occurs. The cyclic voltammograms shown in figure 6(b) were stable for at least 25 scans, demonstrating the high strength of
Table 3. Interference studies of metal ions at a DNA-modified SWCNT mat used as an electrode for the detection of $\mathrm{Cu}^{2+}$.

\begin{tabular}{lllc}
\hline Ion & Concentration & $\begin{array}{l}\text { OSWV difference } \\
\text { peak current }(\mu \mathrm{A})\end{array}$ & $\begin{array}{l}\% \text { difference from } \\
1 \mathrm{n} \mathrm{Cu}^{2+}\end{array}$ \\
\hline $\mathrm{Cu}^{2+}$ & $1 \mathrm{nM}$ & 1.9 & 0 \\
$\mathrm{Ni}^{2+}$ & $1 \mu \mathrm{M}$ & 1.8 & 5 \\
$\mathrm{Co}^{2+}$ & $1 \mu \mathrm{M}$ & 1.8 & 5 \\
$\mathrm{~Pb}^{2+}$ & $1 \mu \mathrm{M}$ & 1.6 & 15 \\
$\mathrm{Zn}^{2+}$ & $5 \mathrm{mM}$ & 1.7 & 10 \\
\hline
\end{tabular}

binding of copper to DNA [24, 25] and suggesting that one $\mathrm{Cu}^{2+}$ ion optimally binds to nitrogen and/or oxygen atoms of two DNA bases, probably with square planar geometry [24]. Further tests on the stability of the DNA-modified SWCNT mat electrode revealed that it could be regenerated without any decrease in response for 5 days, whereupon the current sensitivity began to decrease.

An improvement in the detection limit can be achieved using OSW voltammetry. The lowest concentration detected (figures 6(c) and (d)) was $0.1 \mathrm{nM}$. This sub-parts per billion detection limit shows that the DNA-modified SWCNT mat electrode is suitable for the detection of low levels of metal ions typically found in water samples from the environment.

The selectivity of the DNA-modified SWCNT mat electrode was evaluated by performing an interference study. The choice of metals selected for interfering with copper binding was based on their ability to complex with amine and carbonyl groups and the likelihood of their presence in natural samples from the environment. Table 3 shows the concentrations of individual metal ions that gave measurable changes in redox currents. Currents were lowered as the metal ion was complexed in competition with $1 \mathrm{nM} \mathrm{Cu}{ }^{2+}$. Apart from $\mathrm{Ni}(\mathrm{II}), \mathrm{Co}(\mathrm{II}), \mathrm{Pb}(\mathrm{II})$, and $\mathrm{Zn}$ (II), none of the other metal ions including $\mathrm{Ba}$ (II), $\mathrm{Cr}$ (III), $\mathrm{La}$ (III), and $\mathrm{Ca}$ (II) tested here showed significant interference with the $\mathrm{Cu}$ (II) measurement.

The implications of this work for analytical science are threefold. Firstly, low detection limits for redox-active metal ions were achieved using DNA-modified SWCNT mat electrodes prepared by a facile method. Secondly, a combination of DNA molecules with different base sequences may be used to modify the CNTs providing the potential for tailoring electrodes with enhanced specificity for metal detection, or monitoring a number of different metal ions via arrays of modified electrodes. Lastly, the DNA-modified SWCNT mat electrode prepared here shows great potential for developing stable biosensors. Thus far, the instability of biosensors has been one of the obstacles to their commercialization.

\section{Conclusions}

We have demonstrated a solid phase photochemical reaction for functionalization of sidewalls and tips of CNTs, followed by condensation via an amide linkage to pre-synthesized, single-stranded molecules of DNA bearing a terminal amine group. The reaction was demonstrated in two types of CNT platform, as vertically-aligned MWCNTs on a solid support 

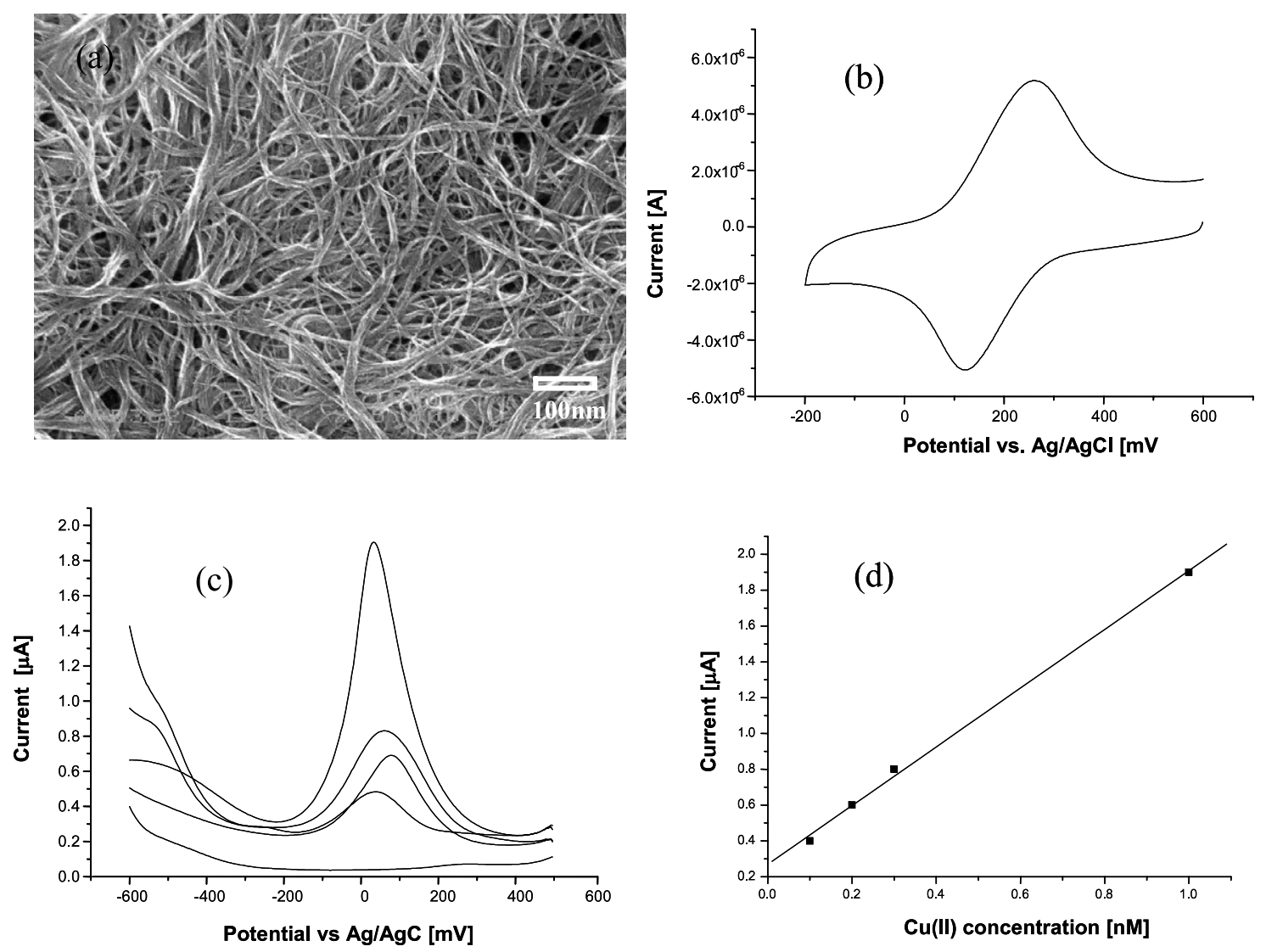

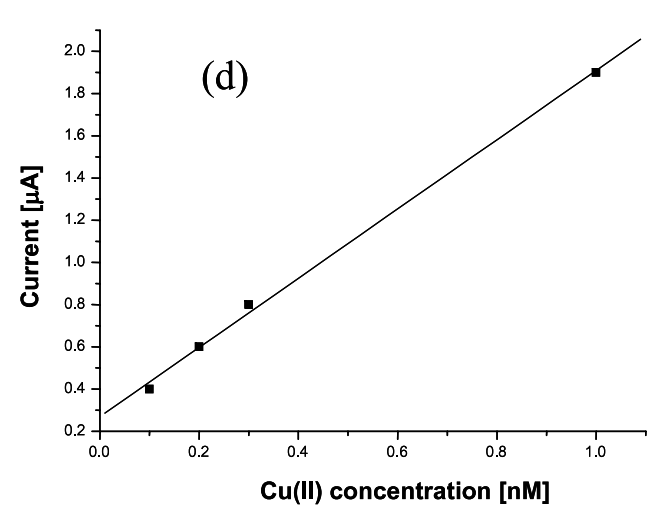

Figure 6. Use of a DNA-modified SWCNT mat as a working electrode to detect copper ions. (a) SEM image of a mat of bundled SWCNTs with functional ss-DNA attached to the surfaces. (b) Cyclic voltammogram of a DNA-modified SWCNT mat electrode after pre-concentration for $5 \mathrm{~min}$ in $0.01 \mathrm{mM}$ copper ions. (c) OSW voltammograms of $\mathrm{Cu}$ ions at various concentrations complexed to DNA in DNA-SWCNT mat electrodes after an accumulation time of $5 \mathrm{~min}$ in $0.05 \mathrm{M}$ phosphate buffer (pH 5.5) and 0, 0.1, 0.2, 0.3 , and $1 \mathrm{nM} \mathrm{Cu(II)}$ (bottom to top, respectively). (d) OSW peak current versus concentration of Cu(II) for the DNA-modified SWCNT mat electrode.

and as a SWCNT mat. This facile method could readily be applied to other biomolecules bearing a terminal amine group, such as proteins, enzymes and antibodies, to produce diverse CNT-biomolecule hybrid systems, thereby combining useful properties of CNTs with the recognition or catalytic properties of the biomolecules for biomedical diagnostics and other applications.

The advantages of this photochemical process over previous methods reported so far can be summarized by the following: (i) facile derivatization of CNTs in the solid phase using an azide photochemical addition reaction; (ii) functionalization of CNTs with reagents bearing spacers of variable length to enable efficient coupling of large biomolecules such as DNA or proteins; (iii) efficient functionalization on both tips and sidewalls of CNTs; (iv) greater processability of derivatized CNTs compared to non-derivatized counterparts (or oxidized CNTs); and (v) micro- and submicro-patterning by introducing lithographic methods to the photochemical process. The particular advantage of this method is the ease of processing at all stages when using aligned MWCNTs on a solid support or SWCNT mats. Furthermore, there is little loss of sample compared with solution-based methods for functionalizing CNTs, as samples do not need to be centrifuged.
In applications where individual SWCNTs are required to be fully coated with DNA, then starting with a mat of tangled SWCNTs is not ideal, as only those CNTs on the outer surfaces of bundles can be readily functionalized. In this case, the photochemical addition of ANB-NOS, and subsequent coupling with DNA, may be performed as described here but starting with a forest of (small bundles of) SWCNTs standing vertically on a solid support [26], similar to the sample of vertically-aligned MWCNTs on gold foil used here. In this configuration, the SWCNTs are separated and so their sidewalls will be exposed to solutions of ANB-NOS and any desired biomolecule bearing an amine group for subsequent coupling. Once modified, the SWCNTs can be released from the substrate by sonication or other methods, if required.

It is worth noting that this photochemical method can be easily adapted for functionalization, patterning and subsequent attachment of biomolecules to monolayer or multilayer graphene for production of graphene-based biosensing devices.

\section{Acknowledgment}

We thank Dr Bill Gong from UNSW for his assistance in analysis of some XPS samples. 


\section{References}

[1] Yang W, Ratinac K R, Ringer S P, Thordarson P, Gooding J J and Braet F 2010 Angew. Chem. Int. Edn $492114-38$

[2] Tang X, Bansaruntip S, Nakayama N, Yenilmez E, Chang Y-l and Wang Q 2006 Nano Lett. 6 1632-6

[3] Li J, Ng H T, Cassell A, Fan W, Chen H, Ye Q, Koehne J, Han J and Meyyappan M 2003 Nano Lett. 3 597-602

[4] Cai H, Cao X, Jiang Y, He P and Fang Y 2003 Anal. Bioanal. Chem. 375 287-93

[5] He S, Song B, Li D, Zhu C, Qi W, Wen Y, Wang L, Song S, Fang H and Fan C 2010 Adv. Funct. Mater. 20 453-9

[6] Shao Y, Wang J, Wu H, Liu J, Aksay I A and Lin Y 2010 Electroanalysis 22 1027-36

[7] Wang H, Muren N B, Ordinario D, Gorodetsky A A, Barton J K and Nuckolls C 2012 Chem. Sci. 3 62-5

[8] Lee K-J, So H-M, Kim B-K, Kim D W, Jang J-H, Kong K-J, Chang H and Lee J-O 2011 J. Nanomater. 2011105138

[9] Keren K, Berman R S, Buchstab E, Sivan U and Braun E 2003 Science 302 1380-2

[10] Hazani M, Hennrich F, Kappes M, Naaman R, Peled D, Sidorov V and Shvarts D 2004 Chem. Phys. Lett. 391 389-92

[11] Williams K A, Veenhuizen P T M, De La Torre B G, Eritja R and Dekker C 2002 Nature 420761

[12] Yang W R, Thordarson P, Gooding J J, Ringer S P and Braet F 2007 Nanotechnology 18412001
[13] Li S, He P, Dong J, Guo Z and Dai L 2004 J. Am. Chem. Soc. 127 14-5

[14] Yang R, Tang Z, Yan J, Kang H, Kim Y, Zhu Z and Tan W 2008 Anal. Chem. 80 7408-13

[15] Müller K, Malik S and Richert C 2010 ACS Nano 4 649-56

[16] Moghaddam M J, Taylor S, Gao M, Huang S, Dai L and McCall M J 2004 Nano Lett. 4 89-93

[17] Yang W, Moghaddam M J, Taylor S, Bojarski B, Wieczorek L, Herrmann J and McCall M J 2007 Chem. Phys. Lett. $443169-72$

[18] Huang S, Dai L and Mau A W H 1999 J. Phys. Chem. B 103 4223-7

[19] Liu J et al 1998 Science 280 1253-6

[20] Frens G 1973 Nature (Phys. Sci.) 241 20-2

[21] Wong E L S, Chow E and Gooding J J 2007 Electrochem. Commun. 9 845-9

[22] Clever G H, Polborn K and Carell T 2005 Angew. Chem. Int. Edn 44 7204-8

[23] Yang W, Chow E, Willett G D, Hibbert D B and Gooding J J 2003 Analyst 128 712-8

[24] Clever G H, Kaul C and Carell T 2007 Angew. Chem. Int. Edn 46 6226-36

[25] Clever G H and Carell T 2007 Angew. Chem. Int. Edn 46 250-3

[26] Yu X, Chattopadhyay D, Galeska I, Papadimitrakopoulos F and Rusling J F 2003 Electrochem. Commun. 5 408-11 